\author{
ДИСТАНЦІЙНЕ НАВЧАННЯ ФРАНЦУЗЬКОЇ МОВИ: \\ МОВНА ЧИ МОВЛЕННЄВА КОМПЕТЕНЦІї \\ FRENCH DISTANCE LEARNING: \\ LANGUAGE OR SPEECH COMPETENCE
}

УДК 37.022

DOI https://doi.org/10.32843/26636085/2020/24-1.7

\section{Архіпова т.л.,}

канд. пед. наук,

доцент кафедри інсорматики,

програмної інженерії та економічної

кібернетики

Херсонського державного університету

Гоменюк 3.П.,

спеціаліст вищої категорії,

вчитель-методист фрранцузької мови

Херсонської спеціалізованої школи

I-III ступенів № 27 з поглибленим вивченням інформатики та іноземних мов Херсонської міської ради

Архіпова К.С.,

аспірантка Інституту перекладачів

Київського міжнародного університету
Стаття присвячена особливостям формування мовної та мовленнєвої компетенції у традиційний та дистанційний спосіб. Розглянуті основні комунікативні вміння: уміння розуміти зі слуху співрозмовника, аудіозаписи носіїв мови; уміння здійснювати монологічне та діалогічне мовлення (ставити запитання, реагувати на репліки співрозмовника та розповідати); уміння читати адаптовані та автентичні матеріали для отримання інсормації для подальшого використання; уміння спілкуватися в письмовій фрормі. Визначена доцільність використання інфрормаційно-комунікативних технологій (IКT) для формування мовних та мовленнєвих умінь та навичок у різних видах мовленнєвої діяльності. Відмічено, що для виконання завдань для розвитку уміння розуміти та слухати можна скористатися телесоном, Viber, WhatsApp, Skype, Classroom ma Zoom, а для вміння розмовляти з кількома співрозмовниками доцільно використовувати сучасні інсрормаційні сервіси Zoom, Classroom. Визначено, що особливо ефрективним $\epsilon$ використання IKT для писемного спілкування, для чого достатньо обрати e-mail, соціальні мережі (Facebook, Twitter, Youtube, Linkedln, Instagram, Telegram) та чати. Пі час карантину переконалися в тому, що завдяки інсрормаційно-комунікаційним технологіям фуункція контролю може частково бути перекладена на комп'ютер, зокрема там, де доречні тести. Звернено увагу на розвиток соціокультурної та соціолінгвістичної компетенції для ознайомлення учнів із культурою Франції, мовленнєвими реаліями та мовленнєвою поведінкою. Наведені зразки завдань, які реалізують комунікативні компетентності у традиційній класно-урочній системі. Навчання аудіювання, усного мовлення (монологічного та діалогічного), читання адаптованих та автентичнихтекстів та письма здійснюється інтегровано. Відмічено дисреренційований підхід до опанування різних видів мовленнєвої діяльності. Закцентовано увагу на потребі вчителів піклуватися про здоров'я школярів, що вимагає визначення часу, протягом якого дитині підліткового віку можна знаходитися перед екраном комп'ютера. Зроблено висновки про те, що під час дистанційного навчання послаблюється зворотний зв'язок та збільшується обсяг необгрунтованої самостійної роботи для опанування навчальним матеріалом. Подальший напрямок дослідження визначено у вдосконаленні використання IKT у розвитку мовленнєвої компетенції.

Ключові слова: дистанційне навчання, фрранцузька мова, інфрормаційно-комуні- кативні технології, комунікативна компетентність, мовна та мовленнєва компетенції, аудіювання, монологічне та діалогічне мовлення, читання, письмо.

The article is about peculiarities of language and speech competence formation during traditional and distance learning. The main communicative abilities are described. They are skill to understand interlocutor while listening him, language recordings; skill to complete the monologue and dialogue speech (ask questions, react the interlocutor's speech and tell); skill to read adapted and authentic materials to get the information for the further usage; skill to communicate in a writing form. The practicability of Information and Communicative Technologies (ICT) usage is defined for the language and speech abilities and experience in the different areas of speech activities formation. The article emphasizes that phone, Viber, WhatsApp, Skype, Classroom and Zoom are necessary to use while completing the tasks of understanding and listening development. Modern information services like Zoom, Classroom are necessary to use while development of the communication skill with the several interlocutors. The article describes that ICT for the writing communication (e-mail, social networks like Facebook, Twitter, YouTube, LinkedIn, Instagram, Telegram) and chats are very effective. ICT can allow providing control function, at least partially, using $P C$, as quarantine proved. For instance, it is about the area having tests. The attention is paid at the development of social cultural and social linguistic competence to find out more about culture, speech realities and language behavior of France. There are samples of tasks providing communicative competencies in the traditional classroom system. Learning of listening, speaking (monologue and dialogue), reading of adapted and authentic texts and writing is carried out integrated. The specific approach towards the different types of speech activities is described, as well. The article emphasizes on the teachers attention to the pupils health. It is necessary to define the correct time for the teenager to be near PC. The conclusion of the article is about the feedback weakening while distance learning. As well as about increasing of the insupportable individual study for learning material acquirement. The further development of research is about the ICT improvement in the speech competence development.

Key words: distance learning, french, information and communications technologies, communicative competence, reading, language and speech competence, listening, monologue and dialogic speech, writing. 
Постановка проблеми в загальному вигляді. Пандемія Covid-19 кинула виклик усьому людству. Над світом нависла страшна загроза. Події сьогодення внесли корективи у звичайний уклад життя всіх громадян. Виникли великі проблеми в багатьох сорерах людської діяльності. Не обійшли вони стороною і освітян, які залишилися сам на сам із труднощами. Кожен із них мусить вирішувати їх самотужки, бо суспільство не готове до розв'язання низки завдань щодо організації навчального процесу здобувачами освіти.

На жаль, не всі вчителі забезпечені сучасними гаджетами, а саме: ноутбуками, смарторонами, які б задовольнили потреби успішної продуктивної цифрової освіти. Відсутній необхідний цифровий навчальний контент. Немає доступу до високошвидкісного Інтернету, тому під час дистанційного навчання освітяни змушені до 16 годин на добу працювати в мережі. Від освітян вимагають додаткову роботу, не передбачену чинними нормативними документами. Але життя не стоїть на місці. Учителі навчаються разом із учнями і вирішують такі навчальні проблеми, як використання інформаційно-комунікаційних технологій, зокрема під час вивчення іноземної мови.

Аналіз останніх досліджень і публікацій. Проблема дистанційного навчання сьогодні надзвичайно актуальна. Питання використання IKT висвітлювалося в дослідженнях багатьох науковців, як вітчизняних, так і зарубіжних. Формуванню інформаційно-цифрової компетенції присвячено праці науковців В. Вебер, С. Джон, Д. Докен, Н. Морзе, О. Спіріна. Використання соціальних мереж, їхньої ролі в житті людини, можливостей Інтернету в освіті вивчали І. Захарова, М. Згуровський, М. Кастільс, Є. Полат. Науковці розглядають зазначену проблему в різних напрямах: застосування хмароорієнтованого середовища в освіті (О. Коротун); особливості спілкування у процесі дистанційного навчання (В. Баженова, П. Марков), інноваційні методи у вивченні французької мови (О. Бігич, М. Моро, О. Чурсінова).

Виділення не вирішених раніше частин загальної проблеми. Науковці плідно працюють у розв'язанні проблеми дистанційного навчання здобувачів освіти. Незважаючи на наявність наукових досліджень із цієї проблеми, потребує подальшого вивчення методика впровадження IKT у вивчення іноземної мови. Більшість учителів звикла до фрормування знань, яке ґрунтується переважно на системі доказів текстових книжкових знань. Водночас, спираючись на наукові напрацювання 3 питання дистанційного навчання учнів, залишаються актуальними осо- бливості застосування сучасних освітніх технологій в опануванні фрранцузької мови. Складність полягає в тому, що ця проблема перебуває на перетині двох предметних галузей, таких як новітні інорормаційні технології та іноземна мова.

Мета статті. На сучасному етапі розвитку педагогічної науки активне використання нових IKT та процес передавання знань на основі IKT $€$ актуальним завданням сьогодення. Тому за мету нашої статті ставимо виявити, які саме навички фрормуємо під час дистанційного навчання фрранцузької мови: мовні чи мовленнєві.

Виклад основного матеріалу. Інтеграція України до світової спільноти, наближення її до європейських стандартів вимагає знання іноземних мов для сучасної людини. Цілі, зміст Програми 3 іноземних мов від загальноосвітнього закладу середньої освіти (33СО) були визначені відповідно до Рекомендацій Ради Європи: «Головна мета навчання іноземної мови в загальноосвітніх навчальних закладах полягає у фрормуванні в учнів комунікативної компетенції, базою для якої $€$ комунікативні вміння, сформовані на основі знань і навичок» [3, с. 3]. Саме середня школа $€$ тим навчальним закладом, де передбачено практичне опанування учнями мовленнєвих вмінь та навичок, необхідних для спілкування у чотирьох видах мовленнєвої діяльності, а саме: аудіюванні, говорінні, читанні, письмі. В основу вивчення іноземної мови покладено принцип інтеграції, що забезпечує оволодіння усіма видами мовленнєвої діяльності в їхній реальній послідовності та взаємозв'язку (див. рис. 1 [3, с. 4]).

Особливої уваги потребує фрормування соціокультурної та соціолінгвістичної компетенції, яка сприяє входженню та соціалізації особистості в новому суспільстві.

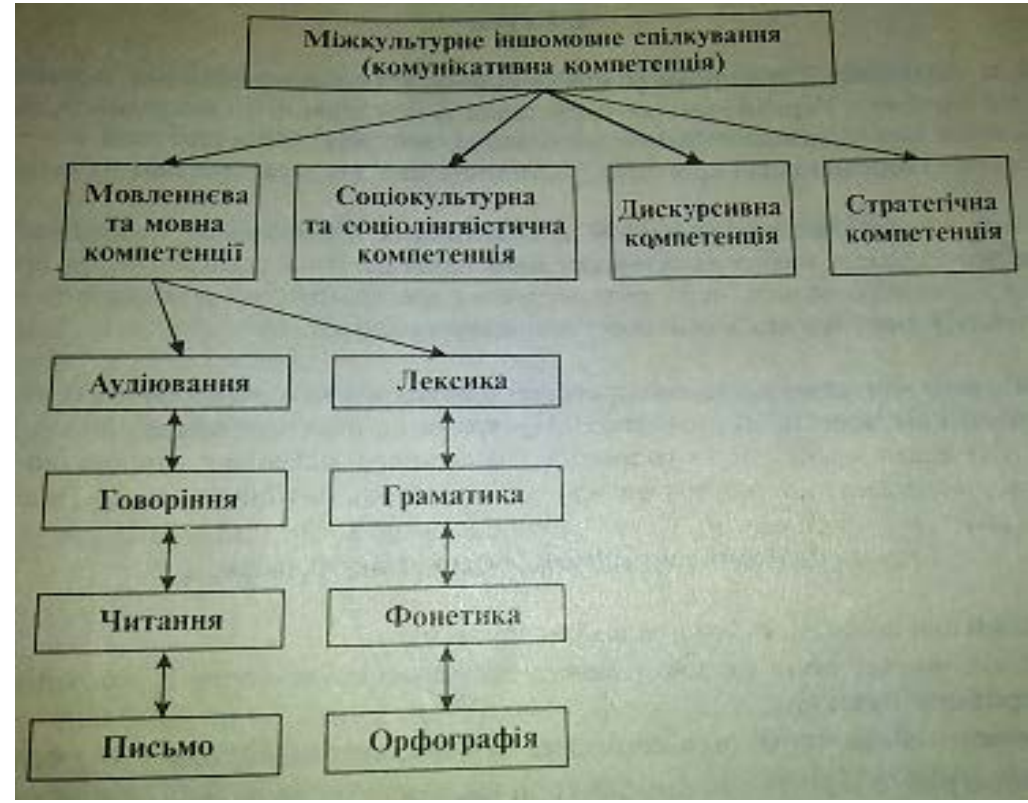

Рис. 1. Міжкультурне іншомовне спілкування 
Дискурсивна компетенція досягається шляхом логічних міркувань. Стратегічна компетенція - це уміння використовувати знання для розв'язання комунікативних завдань.

Проте пріоритетним у фрормуванні комунікативної компетенції є орормування мовленнєвої компетенції, базою для якої слугує оволодіння засобами усного та писемного мовлення. Звернемось, наприклад, до вивчення теми «Здоров'я». Гарне знання лексики та граматики сприяє швидкому розвитку комунікативної компетенції. В основу оволодіння лексико-граматичним матеріалом покладено принцип випереджувального усного засвоєння мовленнєвих зразків, тому що мовлення, насамперед, існує в усній фрормі. 3 метою актуалізації раніше вивченого матеріалу повторюємо лексику 3 теми «Le corps». Ознайомлення 3 новим матеріалом починаємо з розкриття значення лексичних одиниць із використанням електронних носіїв. Для цього використовуємо малюнки, фрото, картинки, жести, міміку, демонстрацію предметів, звертаємо увагу на інтернаціональну лексику. Унаочнення сприяє легшому запам'ятовуванню матеріалу, особливо тим, у кого більш розвинена зорова пам'ять. Саме тут $€$ сенс використовувати власноруч створені вчителем презентації у Microsoft PowerPoint. Хорова фрорма роботи (повторення матеріалу всіма учнями одночасно) знімає страх в учня помилитися, неправильно вимовити або щось сказати, збільшує участь учнів у мовному процесі. Парно-групова, парна робота, струмочок (один за одним), інсценування, карусель, акваріум тощо сприяють фрормуванню вмінь та навичок комунікації, вселяють віру в себе, бажання висловитися. Групова діяльність спонукає учнів активніше працювати, бути впевненим у собі, дозволяє переконатися у правильності своїх міркувань, спілкуватися з однокласниками та, найголовніше, - почуватися комфортно, затишно.

Організаціятакихвидів робітудистанційнийспосіб є практично нереальною, тому що влаштування навчального процесу як ігрової ситуації і задіяння для цього можливості нових інформаційних сервісів, призначених для навчання, навряд чи змоделюють умови реальних подій, оскільки діти знаходяться на відстані й ізольовані один від одного.

Добираємо такі види вправ і завдань, які мають комунікативну спрямованість, а навчальні дії учнів чітко вмотивовані. Добрі знання лексико-граматичного матеріалу ще не є комунікативними уміннями, це тільки основа розуміння усного та писемного мовлення. Тому розвиваємо вміння оперувати цим матеріалом:

1) уміння розуміти зі слуху співрозмовника, аудіозаписи носіїв мови;

2) уміння здійснювати діалогічне та монологічне мовлення (ставити запитання, реагувати на репліки співрозмовника та розповідати);
3) уміння читати адаптовані та автентичні матеріали для отримання інорормації для подальшого її використання;

4) уміння спілкуватися в письмовій формі.

щодо вміння розуміти та слухати, то такі завдання можна виконати, наприклад, за допомогою телефону, Viber, WhatsApp, Skype, Classroom та Zoom. Але всі ці вправи будуть виконуватися учнями, навіть якщо вони зберуться цілим класом, без взаємної участі та взаємодопомоги. До того ж учителю важко виокремити тих учнів, які в першу чергу потребують його допомоги. Тому природною $€$ вірогідність виникнення прогалин у формуванні мовленнєвої компетенції учнів.

Якщо маємо на увазі вміння розмовляти 3 кількома співрозмовниками, то сучасні інформаційні сервіси Zoom, Classroom та інші надають такі можливості, але потребують багато часу на осмислення та висловлення вголос власних думок. На відміну від цього, в аудиторії час на такі роздуми в учнів практично завжди є.

Уміння читати адаптовані та автентичні тексти потребує від учнів великої напруги. Коли учитель працює з одним чи двома учнями з текстом на навчальній платорормі, він не завжди має можливість тримати під контролем інших учнів. Тому існує вірогідність, що решта учнів буде займатися власними справами.

Широке застосування інформаційних технологій ефективно впливає на спілкування в писемній формі. Для проведення такої роботи необов'язково обирати складні інфрормаційні сервіси, тому що такі завдання можна виконувати за допомогою е-mail, соціальних мереж (Facebook, Twitter, Youtube, LinkedIn, Instagram, Telegram) та чатів.

При цьому головним завданням для вчителя була і залишається необхідність піклуватися про здоров'я учнів. Сьогодні час перебування дитини перед екраном є питанням дискутивним. Слід також врахувати те, що дистанційне навчання відбувається 3 кількох предметів на день. У дитини повинен залишатися час на відпочинок, хобі, спілкування 3 друзями. Якщо переглянути документи, що регламентували час перебування дитини за комп'ютером раніше [1], та проекті [2], який знаходиться сьогодні на обговоренні учительською спільнотою, учні підліткового віку можуть працювати з ТЗН не більше 20-25 хвилин. Часу на опанування навчального матеріалу, що потребує від дитини високої активності та великої мозкової напруженості, навіть завдяки вибору вчителем найефективнішого інфрормаційного сервісу, залишається обмаль.

Але слід відзначити, що навчання усіх видів мовленнєвої діяльності відбувається інтегровано. Під час вивчення фрранцузької мови реалізуємо диференційований підхід до освоєння різних видів мовленнєвої діяльності. Так, наприклад, навчаючи діалогічного мовлення, не можна виконувати 
вправи, які сприяють розвитку монологічного мовлення. Навчаючи аудіювання, широко застосовуємо технічні засоби, які дають змогу кожному учневі чути носіїв мови. Це впливає на правильну вимову, ритміку, темп. Розучування пісень, римівок також сприяє розвитку аудіативних навичок.

У традиційному навчанні широко застосовуємо завдання:

1. Associe les mots avec les images.

2. Classez les expressions dans le tableau

(une allergie-attraper-un rhume-avoir des douleurs-avoir le nez qui coule-être asthmatique-faire une piqûre-prendre de l'ibuprofène-se faire vacciner) ()

\begin{tabular}{|c|c|c|}
\hline $\begin{array}{c}\text { es } \\
\text { symptomes }\end{array}$ & La maladie & Les soins \\
\hline & & \\
\hline
\end{tabular}

3. Classez les phrases dans l'ordre.

4. Choisissez la bonne réponse.

5. Recopie la liste des mots en mettant d'un côté la spécialité du medecin, de l'autre les noms de maladies: (Grippe, angine, cardioloque, dentiste, rhume,pédiatre,bronchite, taux.)

6. Trouvez la liste des symptômes des maladies suivantes(un rhume, COVID-19, une grippe).

7. Trouvez l'intrus.

8. Réponds en employant des professions medicales.

9. Répondez aux questions

10. Vous vous sentez mal. Vous allez chez le médecin. Jouez la scène.

11. Vous vous sentez mal. Vous demandez des instructions au téléphone.

12. Décris l'image (l'affiche).

13. Corrige, si tu n'es pas d'accord.

14. Donnez des conseils pour être en forme.

15. Parlez de la situation actuelle en Ukraine, dans le monde pendant la quarantaine COVID-19 .

16. Parle de la célébrité scientifique ukrainienne (française): M. Amosov, Louis Pasteur.

17. Vous étes tombé, vous avez cassé la jambe. Vous écrivez un mail à votre chef que vous ne pouvez pas venir travailler. Utilisez les expressions: (se promener dans la rue, tomber, casser la jambe, ne pas pouvoir venir travailler, appeler le médecin).

18. Ecrivez deux curriels. 1. Ton ami va mal; 2. Tu lui reponds et donnes des conseils.

Особистісно зорієнтований підхід до навчання, зв'язок із життям ефективно впливають на засвоєння навчального матеріалу.

Особливе значення в навчальному процесі має чітко налагоджений контроль. Ми ще раз переконалися в тому, що завдяки інформаційним технологіям ця функція вчителя може частково бути перекладена на комп'ютер, зокрема там, де доречні тести. Учитель перевіряє рівень навчальних досягнень учнів за допомогою тестів. Таким чином, у нього збільшується час на комунікативну діяльність вихованців. Тести можна створити в Microsoft PowerPoint та Microsoft Excel, що не потребує додаткової підготовки, або за допомогою Google Формы, які є простими у використанні не тільки для вчителя, а й для дитини.

Висновки. Проблеми, які виникли під час карантину COVID - 19, загострили увагу як науковців, так і практиків до реалізації аспекту вивчення мови чи мовлення під час дистанційного навчання фрранцузької мови. Дитина живе в соціумі, а під час дистанційного навчання втрачається живе спілкування, взаємодопомога, взаємовиручка, активна взаємодія між учнями. При цьому послаблюється зворотний зв'язок та збільшується обсяг необґрунтованої самостійної роботи для опанування навчального матеріалу. На нашу думку, учні повинні зустрічатися 3 учителем віч-на-віч, тому що вчитель - це джерело радості, натхнення та індикатор успіху дитини.

Подальший напрямок дослідження вбачаємо у вдосконаленні використання IКТ у розвитку мовленнєвої компетенції.

\section{БІБЛІОГРАФІЧНИЙ СПИСОК:}

1. Державні санітарні правила і норми роботи 3 візуальними дисплейними терміналами електронно-обчислювальних машин: ДСанПін 3.3.2.007-98. [Чинний від 1998-10-12]. Київ : МОЗ України, 1998. 19 с. (Державні санітарні норми України).

2. Про затвердження Санітарного регламенту для закладів загальної середньої освіти : Проект наказу Міністерства Охорони Здоров'я України. Доступ: https://moz.gov.ua/article/public-discussions/ proekt-nakazu-ministerstva-ohoroni-zdorovja-ukrainipro-zatverdzhennja-sanitarnogo-reglamentu-dljazakladiv-zagalnoi-serednoi-osviti.

3. Програма для спеціалізованих шкіл 3 поглибленим вивченням Іноземних мов 1-11 класи / Міністерство освіти і науки України. Київ, 2010. 128 с.

4. Програми для загальноосвітніх навчальних закладів фрранцузька мова, іспанська мова 2-12 класи / Міністерство освіти і науки України. Київ : Шкільний світ, 2001. 35 с.

5. Claire Miquel, «Vite et bien A1/A2», Métode rapide pour adultes. CLEinternational, 2009. 192 p.

6. Gaël Crépieux, Lucie-Olivière, Caroline Sperandio, «Vocabulaire essentiel du français». Les éditions Didier, Paris, 2012. 252 p.

7. Colette Samson, Amis et Compagnie A1, CLE International/Sejer, 2008. 128 p.

8. Colette Samson, Amis et Compagnie A2, CLE International/Sejer, 2008. 128 p. 